\title{
PRIVILEGE, POSTURE AND PROTECTION "RELIGION" IN THE LAW
}

\author{
JONATHAN WEISS $†$
}

"It was a ... part of the said scheme and artifice to defraud that the defendants ... did create, organize and operate a ... movement known as the 'I Am' movement and by means of false and fraudulent representations, pretenses and promises hereinafter more particularly set forth, solicit, induce, encourage, persuade and entice the persons to be defrauded to become members and followers of the said 'I Am' movement." I To this indictment, the defendants, the leaders of the movement, demurred, saying that the indictment and prosecution sought "to attack the establishment of said religion or religious beliefs, or to prohibit or restrict the free exercise thereof, contrary to the Constitution of the United States and the law of the land."2 The issue thus was joined in United States $v$. Ballard, ${ }^{3}$ a case of conflict between religious expression and criminal law. The problems, issues and theories raised by the two conflicting positions-the one regarding the movement as a scheme to defraud; the other, as a religion protected from prosecution-will be the starting point for this article's exploration of the meaning and implications of a legal conception of privacy in the realm of religious expression. From this basis we will seek to arrive at tools for adjudication and analysis in all cases where religious rights are claimed by one of the parties.

The "I Am" movement embraced many doctrines. The Ballards professed to be divine messengers. Some of the leaders claimed to have met Saint Germain and Jesus Christ. In particular, they claimed to have attained a supernatural state of "self-immortality" which enabled them to heal persons of injuries and diseases, including some that were classified by medicine as incurable. Members were told to abstain from meat and stimulants, and to study books published and sold by the Ballards. ${ }^{4}$ The Ballards kept their organization functioning by using the mails : members wrote letters to each other, sent and received records, books, magazines and contributions through the post office. All the judges dealing with the litigation assumed that "I Am" was a religion. We will not make that assumption, but instead will analyze the

†Legal Staff of U.S. Department of Labor. I owe an infinite debt of gratitude to Professor Joseph Goldstein, who has been a continuing source of guidance and inspiration.

1. Indictment, Count 1(a), set forth in Record, vol. 1, pp. 4-5, United States v. Ballard, 322 U.S. 78 (1944) [hereinafter called Record].

2. Demurrer to Indictment, Paragraph II, Record; id. at 64.

3. 138 F.2d 540 (9th Cir. 1943), rev'd, 322 U.S. 78 (1944), on remand, 152 F.2d 941 (9th Cir. 1946), rev'd, 329 U.S. 187 (1946). Cf. 35 F. Supp. 105 (S.D. Cal. 1940).

4. All these facts were asserted in the Indictment, Record, supra note 1, at 8-20; see also id., vol. 2, pp. 814-21, vol. 3, pp. 123-65, 953-1178. At the trial, the meaning of some of the claims was disputed. An appendix to Respondent's Brief in the Supreme Court reproduces the text of a 1937 radio broadcast revealing some of the group's claims. 
definitional problem in such a way that we can determine precisely how and when religion enters the case.

Federal law makes it criminal to obtain money through the mails by false pretenses. ${ }^{5}$ It was this statute which the Ballards were charged with violating. The elements of the crime-the fraudulent scheme, an intent to defraud, and a use of the mails ${ }^{6}$ - seem to have been interpreted broadly. It has been held that the fraudulent scheme must dominantly characterize some part of the business. ${ }^{7}$ Although the victims need not have suffered pecuniary loss, ${ }^{8}$ fraud must be predicated on more than disagreement of some with the accused. As for intent, Learned Hand dealt with the matter as follows: "It was only necessary in the case at bar that the defendants had no belief that they would perform the promises held out to prospective members." $\mathrm{He}$ concluded that the jury could reasonably infer intent from the nature of the promises and the difficulty of fulfilling them. Finally, the statute is violated if the mail is in fact used, even if the use be incidental and unpremeditated. ${ }^{10}$ Only the third element is indisputably present in Ballard.

Prior to Ballard, Crane v. United States ${ }^{11}$ showed how easy it is to intertwine the two elements of misrepresentation and intent in a "religious" prosecution. The Crane court upheld a conviction of a man who advocated "mental healing" and wrote tracts in which he said, "I am God." The issue tendered was whether he had made his representations in "good faith."12 Such a view-

5. 18 U.S.C. $\S 1341$ (1958).

6. Stunz v. United States, 27 F.2d 575 (8th Cir. 1928), stated the three necessary elements. See West v. United States, 68 F.2d 96 (10th Cir. 1933) (knowledge that representations are false); United States v. Zalewski, 29 F. Supp. 755 (W.D. Kan. 1939) (intent). Throughout the analysis of the Ballard case, it is assumed that there must be a specific misrepresentation included in the fraudulent scheme. This assumption could be questioned by reference to considerable authority such as Linden v. United States, 254 F.2d 500 (1958), which holds that a specific misstatement is not necessary. But it would seem that a particular item of deceit is a necessary element of fraud, for otherwise there is no falsity but merely, for example, betrayal of confidence. Whether betrayal of confidence is a basis for fraud, absent a representation of trustworthiness, is ambiguous in the cases. See Parr v. United States, 363 U.S. 370 (1959). In any event, it would seem hard to predicate fraud for religion as a whole under the Constitution, so we are driven to find specific misrepresentations, and in this case the indictment alleges them. If a particular item of deceit is not a requisite element, some of the conceptual analysis would lose its neatness but not its logic; the subsidiary attacks on fusing of the requisite elements would lose some of their justice with respect to the deceitful defendant's position. See infra note 17.

7. McLendon v. United States, 2 F.2d 660 (6th Cir. 1924); Graham v. United States, 102 F.2d 436 (2d Cir.), cert. denied, 307 U.S. 643 (1939).

8. Wine v. United States, 260 Fed. 911 (8th Cir. 1919).

9. Knickerbocker Merchandising Co. v. United States, 13 F.2d 544, 546 (2d Cir. 1926). But see Norton v. United States, 92 F.2d 753 (9th Cir. 1937).

10. Hendersor v. United States, 202 F.2d 400, 405 (6th Cir. 1953).

11. 259 Fed. 480 (9th Cir. 1919). A similar result was reached in: New v. United States, 245 Fed. 710 (9th Cir. 1917), which upheld the conviction of Bishop New since he was not "the immaculate personage he pretended to be." Id. at 721.

12. 259 Fed. at 482. 
point intertwines misrepresentation and intent because it makes a finding of misrepresentation rest on an analysis of intent. We may suggest that this fastening on "good faith" is a consequence of the absence, in this area of the law, of common criteria for evaluating the truth or falsity of representations. ${ }^{13}$

The government's theory in Ballard as to which particular representations were false was not constant throughout the litigation, but the veracity of the claims concerning healing and other powers (e.g., immortality and ascension), the honesty of belief of the leaders in their representations and religion, and the truth of the religion as a whole, were each questioned at various times. The case suggests the following issues. (1) What is the domain of religion and how do we proceed to define and apply it to legal problems? (2) What comprises a fraudulent representation? (3) What comprises a religious expression? (4) What is religious expression in its different manifestations: belief, ritual, action? How do we classify claims labeled as religion in domains where other authorities traditionally hold sway? In Ballard, for example, certain claims conflict with medical theory. (5) Is there a distinction between religious belief and action?

These five issues can be approached from two directions. First, Ballard presents the problem of fraud in religious representation. An understanding of the concepts "representation," "religion" or "fraud" may solve this "case. The inquiry into representations and religion can focus on the first element of the crime of mail fraud-what constituted a fraudulent scheme? Second, there is the problem of at what point the first amendment enters discussion of a situation which may affect freedom of religion, and what it commands. Our inquiry will seek to understand how religion is related to representations, with an eye to when the first amendment should be invoked. We will have to confront the problem of whether a representation can be religious, whether it can be fraudulent, or whether it can be both. The gravamen of this search will be the effect of the claim of religious characteristic on the application of the mail fraud statute. In the search we will attempt to define for ourselves the nature of religion for the purpose of the law and the first amendment and try to decide its applicability as a defense to the application of this statute.

The Ballard defendants fought their way up to the Supreme Court. During the course of the litigation, the judges involved produced five responses to the apparent clash between the statute and the defense based on the first amendment. The first of these was articulated in the trial judge's charge to the jury, which formed one of the bases for appeal. A statement in conference, which formed the substance of the disputed charge, is as follows:

... Some of the teachings of the defendants, representations, might seem extremely improbable to a great many people. ... As far as this court sees the issue, it is immaterial what these defendants preached or wrote or taught in their classes. They [the jury] are not going to be permitted to speculate on the actuality of the happening of those incidents. . . . The issue is: Did these defendants honestly and in good faith believe these

13. Compare Dolan v. Hurley, 283 Fed. 695 (D. Mass. 1922) on the permissibility of selling lucky stones. 
things? If they did, they should be acquitted. . . . If these defendants did not believe these things, [if] they did not believe Jesus came down and dictated, or that Saint Germain came down and dictated, and did not believe the things that they wrote, the things that they preached, but used the mails for the purpose of getting money, the jury should find them guilty. 14

This view of the problem, which can be labeled the deceitful defendant position, identifies as a jury issue the question whether the defendants lied about their beliefs in order to obtain money. The nature of religion is an irrelevant consideration, since the court conceives of the statute as punishing those who use the mails for personal deceitful aggrandizement. Once the mails have been used, the inquiry for fraud requires an examination, not of the representations of the religion itself, but of the degree of belief the leaders have in them, even in the absence of explicit criteria for a determination of amount of belief.

Speaking for a majority of the Ninth Circuit on appeal from conviction, Judge Mathews offered a second judicial response.

The issues were (1) whether defendants and Guy W. Ballard devised the scheme described ... ; (2) whether, for the purpose of executing the scheme, they used the mails...; (3) whether they conspired to commit any of the offenses charged ... ; (4) whether ... any party ... committed any ... overt acts. ${ }^{15}$

Because the question "whether such representations were false or true" was not submitted to the jury, the Ninth Circuit granted a new trial. ${ }^{16}$

Such a view of the problem, which may be called the factual fraud position, seems to look to the effects that the judges feel the statute was designed to prevent. Unlike the deceitful defendant approach the factual fraud position does not examine motive but rather requires an inquiry into the truth or falsity of the representations claimed to be religious. It explicitly rejects the fusing of misrepresentation and intent, and considers the manner of reaching a finding of fraud in this area indistinguishable from the inquiry to be made about any other deceitful commercial scheme.

These judicial positions present two sets of analytic difficulties: The first is the conjunction of religion and truth. What type of representations are capable of being fraudulent? What do we look for in finding fraud? When a belief is offered as "religious," what is being represented? Or, is there no such thing as a "religious" statement for the purposes of the law? Granted that there are statements which may be classified as religious statements, can they be deceitful? The second set questions the factual basis for a finding of fraud. What type of claims and representations are factual in such a manner that they are for the jury? If the evaluation of a religion is involved, is this not a matter involving the First Amendment? In the realm of beliefs not

14. Record, supra note 1, at vol. 1, pp. 402-03, vol. 3, pp. 1475-76, 1545.

15. Ballard v. United States, 138 F.2d 540, 545 (9th Cir. 1943).

16. Ibid. 
claimed to be supported by science or other "objective" disciplines, what is the nature of misrepresentation ?17

Judge Denman, in denying a motion for rehearing, seemed to try to bridge the gap between the deceitful defendant and factual fraud positions.

It would be strong evidence in support of this issue of mental condition of belief, that these transactions with Jesus actually occurred in their presence. The right to produce such evidence was denied appellants [by the ruling that] ... they [the jury] are not going to be permitted to speculate on the actuality of the happenings of these incidents. . . Here we have not only the exclusion of proof and instruction to disregard facts which would strongly tend to support an honest belief that they happened, but a suggestion of their improbability. The error is as prejudicial to the issue of honest belief as to the issue of purposeful misrepresentation. ${ }^{18}$

In brief, Denman suggested that the examination of the accuracy of the representations could have been utilized not only for completing the first element of the crime, the misrepresentation of fact, but also the second element of the crime, the intent to defraud. Such an analysis suggests that the improbability of truth should have an effect upon a decision as to the honesty of belief. ${ }^{10}$ Judge Denman argues that exclusion of factual examination of the religious representations is prejudicial rather than lenient, and that rather than shifting a burden of proof, it offers them an opportunity guaranteed as a right. In Judge Denman's view, then, to deny that religion can be an objective part of every day life is to deny freedom of religion. The implication of his opinion is that religious beliefs are susceptible to ordinary discriminations, so that a factual examination can lead to a finding of fraud in matters of religion. But such a view may dictate a particular meaning for "religion," and seems to rest on the assumption that there are ways of clearly showing that a belief is not religious, or that if it is religious, it is "false."

At the Supreme Court, where the decision was reversed and remanded to the Ninth Circuit for reconsideration, three more responses emerged. Mr. Justice Douglas, writing for the majority, focused on the first amendment and solved the case on narrow grounds, faslioning a view that might be called religious reservation. ${ }^{20} \mathrm{Mr}$. Chief Justice Stone, joined by Justices Roberts

17. In a different approach, Judge Stephens dissented from the Ninth Circuit's decision, merely saying that he was "not convinced that the judge's comments and instructions upon the decisive point of the majority opinion were not more favorable to the defendants than the law required." 138 F.2d at 545. He thus suggested that such an instruction could avoid issues of religious freedom while presenting enough support for a conviction. His reasoning must have been that the defendants weren't put to the proof or defense of their representations-just their honesty. But to say that the question of what is believed can be separated from the question of what is believable seems to carry three implications. (1) That it is impossible to believe that what one is saying is false, and still to tell the truth. (2) That, in fact, the jury could conclude that the defendants were lying both in intention and reality. (3) That, in this case, the idea that the Ballards could believe what they were claiming was a generous notion.

18. Id. at 546.

19. See dissenting opinion by Jackson, J., in Ballard, 322 U.S. 78, $92-93$ (1944).

20. 322 U.S. 78 (1944). 
and Frankfurter in dissent, ${ }^{21}$ combined elements of the deceitful defendant and factual fraud positions into what might be called the clearly culpable theory. Mr. Justice Jackson, in a separate dissent, ${ }^{22}$ took a hands-off approach. ${ }^{23}$

The Chief Justice stated his basic position in the first sentence of his dissent. "I am not prepared to say the constitutional guaranty of freedom of religion affords immunity from criminal prosecution for the fraudulent procurement of money by false statement as to one's religious experience, more than it renders polygamy or libel immune from criminal prosecutions." ${ }^{24} \mathrm{He}$ gave as an example a statement about Ballard meeting Saint Germain at a particular place and time when it could be clearly proved that Ballard was elsewhere. This is a kind of factual fraud. But he also said that "certainly none of respondents' constitutional rights are violated if they are prosecuted for the fraudulent procurement of money by false representations as to their beliefs, religious or otherwise." ${ }^{25}$ This argument recasts the prosecution, by conceiving of the fraud as depending upon whether the defendants actually believed their own representations. If the jury finds that the defendants did not believe their representations to be true, then they have misrepresented a fact. Their intent becomes a representation.

The clearly culpable position thus holds that if it is clear to the jury beyond a reasonable doubt that an item is false as represented, be it belief or what is believed, then the jury has a sufficient factual basis on which to find fraud. Such a theory implies that representations can be divorced from their religious context and that such separated representations can be objectively judged by a jury. That theory perhaps rests primarily on a concern for those who join the religion in the hope of receiving the benefits which have been represented as flowing from it. Given misrepresentations that enticed these people to join, the Chief Justice found that religion did not comprise a defense to the presentation of evidence any more than it would for bigamy. He saw religion as in no way altering an investigation for fraudulent representation.

21. Id. at 88. Interestingly enough, Chief Justice Stone's position was followed by the majority on remand from the Supreme Court in the decision below. 152 F.2d 941 (9th Cir. 1945). Further, a Lawyer's Edition annotation cites Ballard for what appears to be his view. $96 \mathrm{~L}$. Ed. 968, 974 (1952). The opinion of the lower court on remand was later reversed on totally different grounds, the exclusion of women from the jury. 329 U.S. 187 (1946). See also 35 F. Supp. 105 (S.D. Cal. 1940).

22. 322 U.S. at 92.

23. In about the only comment on these responses, Justice Brennan stated, "The dilemma presented by the case was severe . . . [vis-a-vis] close adherence to the neutrality principle." School District v. Schempp, 374 U.S. 203, 245 (1963). But, accompanying this comment on the case are two mistaken descriptions as to the requested instructions and affirmance of conviction. Thus, his characterization should not be read as exhaustive of the issues and factors in the litigation. See his comment in Braunfeld v. Brown, 366 U.S. 599, 615 (1961).

24. 322 U.S. at $88-89$.

25. Id. at 90 . 
Mr. Justice Douglas took another tack. He was concerned with the demands of the first amendment, and did not consider whether the fact that challenged representations occurred in the context of a claimed religious movement would affect an examination for fraud. With Justices Black, Reed, Murphy, and Rutledge, the liberal wing of the court, he held that the first amendment commanded exclusion of evidence as to the truth or falsity of the Ballards' religious credos.

Heresy trials are foreign to our Constitution. Man may believe what they cannot prove. ... Religious experiences which are as real as life to some may be incomprehensible to others. ... So we conclude that the District Court ruled properly when it withheld from the jury all questions concerning the truth or falsity of the religious beliefs or doctrines of the respondents. ${ }^{28}$

For Mr. Justice Douglas, the first amendment compels religious reservation-any examination of a religion's "truth" for whatever purposes is forbidden by the Constitution.

But although he repudiated the circuit court's factual fraud approach, Mr. Justice Douglas did not reach the trial court's deceitful defendant view. ${ }^{27}$ Offering no criteria for determining either what is "religious" or what comprises an actual "submission" to the jury, he rejected explicitly the proposition that religious propositions are susceptible to normal factual examination. Such a rejection makes a curious contrast with the position taken by the Chief Justice. Whereas the Chief Justice said that religion should not serve to shield a defendant from a conviction for a criminal offense, Mr. Justice Douglas said that religion can not so serve, because the Constitution forbids analysis of the issues by a jury. Thus, while the Chief Justice regards religion merely as a factor to consider in a scheme of representations, Mr. Justice Douglas would exclude it from the trial altogether. Whereas Mr. Justice Douglas does not consider whether leaders' beliefs are part of the religion, the Chief Justice considers them only as representations connected with a fraud.

The motif of Mr. Justice Jackson's hands-off attack can be found in his last sentence: "I would dismiss the indictment and have done with this business of judicially examining other people's faith."28 His epigrammatic attacks can be used as a basis for rejecting the alternative positions and for beginning the elaboration of an answer to the issues posed by Ballard and suggested in general by the first amendment's religious commands. Mr. Justice Jackson viewed the problem from the vantage of the movement itself. $\mathrm{He}$ argued implicitly against the separation of particular representations from the religion as a whole, and explicitly against the view that religion did not cut across the grain of all the legal issues in the case. His main attack was levelled at the deceitful defendant position. First, he pointed out the difficulty of establishing the amount of sincerity in a religious belief. "I do not know what degree of
26. Id. at $86-88$.
27. $I d$. at 88.
28. 322 U.S. at 95. 
skepticism or disbelief in a religious representation amounts to actionable fraud.... When does less than full belief in a professed credo become actionable fraud" ?29 Second, Mr. Justice Jackson pointed out that "any inquiry into intellectual honesty in religion raises profound psychological problems ... [Religion's] vitality is in the religious experiences of many people." 30 Third, he emphasized that really religious people may not be sincere in the normal use of the word. "Even the most regular of them (unconventional religious teachers) are sometimes accused of taking their orthodoxy with a grain of salt."31

Historically, many have not considered belief necessary either to the honesty of a position taken or its truth. Freud, on one occasion, confessed that he lacked certainty concerning the truth of what he affirmed, stating only that his methodology dictated the answers he gave. In Poland, a "Messiah" recanted under Catholic pressure, and some of his followers still kept faith. The "dark night of the soul" is well known to many who are commonly accepted as religious. Further, the deceitful defendant position mistakes what religion is and the claim it makes on people. Religion is a body of beliefs and affirmations rather than a description of a leader or his opinions. To ask a man to believe your religion does not mean that you ask him to believe you or to believe that you believe, but to assent to propositions represented as being that religion. The quality of the leader's beliefs and motives are not a necessary part of a religious system, except perhaps as an example or inspiration.

It is possible to talk of a deceitful defendant in a way which minimizes inquiry into degree of belief or sincerity, as ordinarily understood. One may contrast Freud, the Polish messiah, and the agnostic or even atheistic priest -each of whom seems to be caught up in the existential involvements of religion or truth-seeking-to a venal businessman, whose only apparent concern is making money, not religious truth. The latter creates a system which will earn him the largest amount of income, and is neither involved in an evaluation of the truth or falsity of religious experience nor concerned with offering his religion for people to evaluate its truth. We could not ask about his "degree of belief" because, for him, such a question is irrelevant. Would his prosecution transgress the values which support Jackson's refutation of the deceitful defendant position?

To find fraud when a leader states "I believe," it is necessary to show two things: first, that the "I believe" is one of the foundations of the religion on which the people are asked to base their assent; second, that a non-religious standard by which the leader invites proof of his belief demonstrates his disbelief when applied to him. Only infrequently is the belief of the leaders offered as a basis for popular assent. Moreover, the first amendment precludes us from establishing religious standards to evaluate religions or the degree of belief involved. So, even in the extreme case in which evidence is presented

29. Id. at $93,95$.

30. Id. at 93 .

31. Id. at 95 . See also id. at 94 . 
as to the leader's disclaimed or disengaged belief, in the absence of a showing that the leader represented his belief as verifiable by some non-religious perspective, and that that perspective proves his non-belief, we cannot convict him for fraud. ${ }^{32}$

The factual fraud position is refuted summarily in Mr. Justice Jackson's opinion.

Belief in what one may demonstrate to the senses is not faith. All schools of religious thought make enormous assumptions, generally on the basis of revelations. . . . The appeal in such matters is to a very different plane of credulity than is invoked by representations of a secular fact in commerce. ${ }^{33}$

In short, religious representations are not like other representations and fraud cannot be predicated on them.

From the factual fraud refutation comes the destruction of the clearly culpable position. Since, in fact, religious representations are not like others it is not at all clear that preachers such as the Ballards can defraud their followers in the ordinary sense of that term or that there can be a particular item of deceit to locate. Mr. Justice Jackson rejected looking at those who joined the religion as people who entered searching for particular benefits which were misrepresented. "If the members of the sect get comfort from the celestial guidance of their 'Saint Germain' . . . it is hard to say that they do not get what they pay for. . . . The chief wrong which false prophets do to their following is not financial." 34 The Ballards offered a system or at least an accumulation of beliefs. As a religion, its "selling point" was its effect taken as a whole. Isolating individual items is a method which ignores the nature of religious participation. The dissection or examination of a religion to discover what advantages were claimed is precisely what the Constitution forbids. ${ }^{3 x}$

Finally, standing alone, the religious reservation position enunciated by $\mathrm{Mr}$. Justice Douglas falls as well. The religious issue permeates the whole prosecution. To follow the first amendment's command forbidding an examination of religion only by proscribing a jury charge relating to religion does not meet the problem.

In the first place, as a matter of either practice or philosophy I do not see how we can separate an issue as to what is believed from considerations as to what is believable. The most convincing proof that one believes his statements is to show that they have been true in his experience. Likewise, that one knowingly falsified is best proved by showing that what he said happened never did happen.... If we try religious sincerity

32. Mr. Justice Jackson in this connection raised many problems. First, he pointed out that an examination of sincerity raises serious difficulties in psychological fact finding. Second, he suggested that leader's belief in a religion is rarely a tenet of the religion. Finally, he stated that any examination of sincerity necessarily requires an examination of the religion itself.

33. 322 U.S. at 94.

34. Ibid.

35. Id. at 95 . 
severed from religious verity, we isolate the dispute from the very considerations which in common experience provide its most reliable answer. ${ }^{36}$

This position suggests that keeping the issue of the truth of the doctrine from the jury is prejudicial on the issue of the sincerity of belief. Reservation of the matter will not work since the heresy trial continues, Mr. Justice Jackson implies, if we question their sincerity. Since religion cannot help but be involved in an examination of sincerity of belief, the Douglas position cannot save the prosecution from first amendment objections.

Mr. Justice Jackson's positive position can be inferred from his attacks. He recognizes and deals with the problem that poor people appear to have been bilked by the Ballards' activity.

I doubt if the vigilance of the law is equal to making money stick by over-credulous people. ...

The wrong of these things, as I see it, is not in the money the victims part with half so much as in the mental and spiritual poison they get. But that is precisely the thing the Constitution put beyond the reach of the prosecutor. ${ }^{37}$

This argument suggests that religion is a domain wholly separate from others, in which traditional standards of fraud do not apply. "Belief in what one may demonstrate to the sense is not faith." 38 Transactions which involve money for religious beliefs-matters of faith-are not in any way reducible to normal transactions, and so the whole inquiry into that realm must be excluded.

The trouble with this inferred position is that it provides no standards for defining faith or religion, and does not focus sharply enough on the issue of what constitute religious and/or fraudulent representations. The fraud originally alleged in the case concerned various representations; the representations, not necessarily the religion as a whole, may have induced people to part with their money. Stone maintained that those representations can be treated separately from the religion. The prosecutor based his argument, in part, on the view that the religion was a cloak for specific misrepresentations dealing with medicine, politics, and certain catastrophic happenings, as well as a tissue of implausible stories about Christian figures. Is it possible to separate these representations? Can a representation be both religious and fraudulent?

More generally, what is "religious"? Can a man legally sell drugs, claiming on the front of the label that they cure cancer, and on the back that God told him this? Can religion be used as a defense to a substantive crime? A man may defend by saying that God told him to murder, but is it sufficient if he

36. Id. at 92-93. As am example of this point, the actual trial is ideal. In proving the lack of sincerity, the prosecutor compared the "ascended masters" of the movement to Charlie McCarthy, the puppet, Superman and Flash Gordon, while suggesting that their method of ascension was stolen by Donald Ballard from Popular Mechanics. Record, supra note 1 , at $1211,1237,1503$.

37. Id. at 94,95 .

38. Id. at 94 . 
announces the basis for his action only after the act?39 Was the Catholic Church not pronouncing religious dogma when it told Galileo to recant? Aren't things demonstrated to the senses often a matter of faith? How do I discover the motives of a man buying? If I buy rotten meat on a type of faith in the advertisement am I still not gypped? Could a butcher defend the sale if he could prove that I thought God ordered me to buy the particular rotten piece of meat, so I got what I wanted? Suppose I solicit funds and ask you to join my religion saying I will meet St. Jerome or the books I sell you tell about St. Jerome and when I am supposed to meet him I am elsewhere or the book has nothing but blank pages? These questions exemplify the difficulty in separating demonstrations to the senses from appeals to faith, in using motives of buyer or seller as relevant to fraud, and in denying that some followers do rely on the existence of concrete benefits from the religion, and believe that concrete events claimed by the religious leaders to have occurred did occur.

The beginning of an answer to the conflict between constitutional mandate and statutory proscription lies in the realization that propositions bring with them implicit presuppositions. Concepts arrive in contexts. To describe or discuss anything implies some type of meeting ground, some commonality of experience and vocabulary. Religious belief provides one such experience and vocabulary; science, another; philosophy, yet another and so on. Intellectual disciplines provide a perspective and system from which we derive the meaning of particular entities. A particular object, or even a particular idea has a different nature depending on the context or the perspective of the discipline or disciplines from which we approach it. A cup of wine may be religious or profane depending on what one does in relation to it.

Given this understanding, we can describe a fraudulent representation. For our immediate purposes, such a misrepresentation may occur in two ways: (a) I can misrepresent the results that a given discipline achieves. I can say that water tests out chemically as $\mathrm{H}_{2} \mathrm{SO}_{4}$ in my laboratory. (b) I can misrepresent what discipline or world perspective I work in. As a layman I can say, "Speaking medically, I will cure you of cancer." Thus fraud may be perpetrated either by misrepresenting what perspective is brought to a problem, or what results obtain therein.

Religion is one type of perspective. Religious expression involves assent to propositions that define the world we live in. A cross, a cup of wine, a candle, a baby's cry, sex,--all have different meanings in different religions for different people. To recognize the plurality of faiths is to recognize the plurality of possible descriptions of these things. What may be a scientific

39. The recent case approving a judicial act which forced a transfusion on a Jehovah's Witness is worth considering here. Application of the President and Directors of Georgetown College Inc, A Body Corporate, — F.2d (D.C. Cir., Feb. 3, 1963) (Misc. No. 2189). Though solved on different grounds, this case seemingly pitted a person's own notion of his meaning in life and what death was to him against the state's interest in his life. The opinion explicitly acknowledges that religious people have no license to commit suicide when non-religious people have no such right. 
aberration to some is a miracle to others. Bad history may be divine scriptures.

Yet to define the limits of religious expression may be impossible if philosophically desirable. Moreover, any definition of religion would seem to violate religious freedom in that it would dictate to religions, present and future, what they must be: inability to give an authoritative definition is justified by the conjunction of the first amendment's two religious clauses. Read together, they define religious freedom but do not establish religion as a defined domain. That is, religious freedom is served by allowing a completely open realm for defining religion rather than by establishing a domain or definition in which religions can freely operate. Furthermore, an attempt to define religion, even for purposes of increasing freedom for religions, would run afoul of the "establishment" clause, as excluding some religions, or even as establishing a notion respecting religion. How then can we handle the problem of claims labeled "religious" in domains where other authorities are generally accepted, where people do not normally assent to perceive an experience in a religious way?

Since we are prevented from prescribing what claims are "religious" by delimiting the bounds of religion, we can only say that those claims are "religious" that are clearly so, either by virtue of their characteristics or explicit labels that lead to recognition of them as such. Since religion is traditionally an area of faith and assent, we may say that a religious claim is one which asks for adherence on the grounds of religious truth, or one which is defined or spoken by its author as religious. Because religion can be in conflict with other disciplines, because it cuts across everyday life, we can only know that a claim is based on religion when we are told that it is. The legal basis for stating that a claim is in the religious domain can be that it is held out as being religious in nature. Such a conception enables us to avoid judicial prescription of the range of religion as well as jury decisions on the question of whether a claim is an issue of "fact" or of "religious belief."

If we combine our notion of fraudulent representations with our conception of religious expression within a legal system predicated upon toleration of all forms of that expression, we obtain the result that there can be no fraud in matters of religious belief. For we grant men the right to choose their religious perspective-a perspective which tells them what the nature of things is. Further, this perspective provides its own standard of application-to say that some water is "holy" is to say that using the standards of that religion the water is "holy." Since all standards are possible, no description using such a standard can be fraudulent. These conclusions follow from two guidelines: first, religion comes to a believer from the act of commitment by faith, a type of assumption and assent, not a persuasion by a series of demonstrations to reason; second, religion defines for itself the meaning of the commonplace. Its definitions are not representations but rather an integral part of the perceived reality of experience generated by the perspective that religion brings with it. Just as water is molecules for a physicist, so is trembling wine, a cup for Elijah. 
Of course not every claim touching upon religion would be protected. A man can misrepresent his authoritative basis-he can fail to make it clear that his claim is based on "religion." If a man simply sells bad drugs and defends on religious grounds, we can find his defense insufficient. For we say: first, you failed to define your claims as religious and they were claims of a nature that would not ordinarily be understood as religious; second, holding yourself out as a drug salesman implied that you spoke with medical authority. To defend now that the drugs you sold were good on religious grounds requires that you must have affirmatively and clearly shown to people at the time of sale that the value of the drugs was rooted in a religious system which they had to affirm in order to perceive that value. If a man pretends to speak with authority he does not have, or acts in such a way as to imply that he speaks with that authority, he is guilty of misrepresentation and fraud. When a man acts publicly in a domain where the normal expectations are of secular contentions, he must make it clear that his claims are made as elements of a faith which describes the nature of things about which he is making the claims. Since the Constitution prohibits defining an area of belief as "religious," a man must make it clear that the beliefs he represents are "religious" if he wants to be free to express them under the constitutional warrant of freedom of religious belief. He has the burden of communicating that he speaks only from the authority of religion. But, once such a burden has been met, then we cannot attack the particular aspects of his faith as fraudulent. We examine the representation in terms of its authoritative referent and predicate fraud accordingly.

What a man presents as a religious claim, then, cannot be attacked. It is only when he makes a representation beyond religious authority that we can apply laws of fraud. For these purposes we employ only the minimal understanding of religious activity for the law that it involve an assent of faith to dogmas and propositions that offer some orientation as to the nature of things. This minimal understanding of principles of claiming religious protection together with the concepts that ideas imply contexts and that man is legally responsible for what he presents himself to be, enables us to hold Mr. Justice Jackson's hands-off position, using Mr. Justice Douglas' argument prohibiting "heresy" trials, while avoiding the realization of Mr. Chief Justice Stone's fear that religion might be used as a cloak for fraud.

We can restate the whole position as follows: A misrepresentation comes about when false characterizations of the objects discussed are made. Characterizations are made as the result of applying a discipline's perspectives or standards to perceived objects. The Constitution removes from condemnation those beliefs that are put forth as religious. If a man clearly presents that which he wishes others to believe or act upon as religious, the Constitution prevents a prosecution for misrepresentation.

For the purposes of this analysis, the representations made by the Ballards can be divided into two major classes. These were those representations which were clearly a part of the religion-the movement being a religion in that it 
called for an assent of faith to its propositions-without specific labeling as such. Its representations as to supernatural characteristics and effects upon the soul require an assent of faith; they are the sort traditionally said to be in the religious domain. The tenor of the presentation by the Ballards would indicate these are a matter of faith. No proof that these representations were "religious" can be made rigorously - each statement was not preceded by a formal call to faith or a formal labeling of religion. That they called for an assent can be seen by using traditional conceptions of faith or by examining the presentation. To make a common sense decision whether a movement is a religion and a claim clearly religious, we look in general to: (a) whether the movement claims through an asking for assent (a rigorous proof of religion would probably refer to grounds of assent); (b) "supernatural" claims traditionally connected with religion; (c) whether the traditional customary activities and trappings of "religion" are present. These forms of representation may be classed as "religious," even if not explicitly held out as related to faith, because they are early recognizable by the person represented to as associated with such a form of assent.

The second broad class of representations were not clearly part of the religion. This class itself breaks down into two categories: those representations which might be said to have induced people to join the religion by forming a "factual" basis for belief in the religion and those representations that were of a sort usually strongly associated with non-religious perspectives. The first variety included allegations of the type that worried the Chief Justice-for example, that Guy Ballard had met St. Germain on Mt. Shasta. This historical event seems like an item which if true would be a reason to believe in Guy Ballard's connection with the divine and a reason to join his faith. Such a "fact" might be undermined by proof that Guy Ballard was in St. Louis at the time. I might say "Chemists agree that I can transform water into sulphuric acid. I am a miracle worker. Worship me." Such a scientific claim would then be the offered basis for assuming the religious belief. The second sub-class is comprised of propositions that most people in a common sense way, or in a way informed by various disciplines, find factually absurd. Moreover, they are propositions that one normally finds discussed in particular contexts of other disciplines. Throughout the case scoffing remarks were made about the Ballards' preference for blue, about the claim that they prevented a San Francisco earthquake, sunk a submarine, could help heal and other achievements.

Should any of these representations be found fraudulent? The first broad class, which would be understood even without explicit labeling as religious, clearly must be immune from the application of the statute. In the second broad class, the second sub-class of claims gives no trouble, for these were consistently identified with the religious perspective. Granting freedom of religion to include religious beliefs in all realms, beliefs are not susceptible to being called fraud when they are clearly identified as part of a religion, however unusual such an identification. The most "preposterous" remarks are 
safe precisely because faith is free. But the first sub-class of claims raises difficulties. These representations sound like facts which, if proved true by specified non-religious perspectives, comprise reasons to make a general assent of faith. The examination for fraud of representations founding a creed is an examination whether acceptance of them can be totally predicated on other standards and whether they are so held out. Under the preceding analysis such a representation totally based and justified on a false application of non-religious standards would appear to be fraudulent. If in this first subclass we can show that the statement was held out as a factual, not a religious, foundation for assent and that the asserted factual basis has been intentionally misrepresented, then we have isolated a representation upon which a prosecution may be based.

The reasons for excluding statements identified by their characteristics or presentation as "religious" from "fraud" is a general fear of "heresy trials." If we allow juries to categorize what representations are really not part of the religion, but were claimed to be facts, then we give license to prosecutions against religious freedom. Rather, it is safer to say that once a movement has clearly been identified with religious overtones to those who hear the representations, we will accept the fact that all the movements' representations come warranted as religious, and entice only as they evoke response and recognition. Though such an account may do violence to the way people actually judge religions for themselves and even to what religion "is," it preserves religious freedom. We cannot allow discriminations in a religion between representations justified by recourse to that religion and representations justified by the application of objective standards, so long as assent and affirmation is sought overall. As the historical claim that Christ arose from the dead is clearly religious, so is any claim which founds a religion so long as it is ultimately connected with assent and other religious concomitants. Only if a claim is clearly taken out of the religious domain by specifically and explicitly representing it as objectively verifiable by others without faith, applying standards drawn from other domains, can we have a fraudulent representation. Even then, prosecution must be couched in terms of the man who makes the fraudulent claim and then seeks the shelter of religion, and not in terms of the religion whose shelter he seeks. Religious freedom dictates that we may not divorce particular representations from a religion taken as a whole, nor may we call them fraudulent when they carry with them a religious warrant. We look to the presentation of the representation to see if its context suggests "religious" connections.

The principle discovered - that the law must not entertain descriptions and accounts of religion - not only solves the problems of the prosecution for re: ligious fraud raised by Ballard, but also serves as the foundation for a realistic approach to a more general application of the first amendment freedoms of religion. A constitutional prohibition against assessing or regulating belief clearly labeled as religious exempts religious belief from prosecution. But what manifestations of this religious belief are protected? The exemption has its 
application in the public world, where action takes place and is regulated. A crucial problem is that of the distinction between religious belief and public action. A traditional feeling about the world of law and the world of religion is that the state may not interfere in the world of religion but that when a man participates in the world of public life he must meet its secular and legal standards. How is one to tell which world one is in and when one crosses over?

Law we can say is yet another perspective, but an unusual one. Rather than a descriptive framework, it is, loosely speaking, a prescriptive system for action. It demands and proscribes particular activities-establishes norms of action. Lawyers apply the demands and proscriptions. There is no defense to the application of law. But, under the Constitution there is an exemption which applies when the act in question takes place in the realm of belief or religious perspective.

There is an aspect of our solution to the Ballard case that we need to focus on in connection with this discussion. Throughout the discussion we talked of the privacy of an act of affirmation. We did not precisely define what we meant by privacy nor will we entirely. Rather we have to distinguish three realms of behavior: (1) the realm of pure belief that everybody would grant is private; (2) the realm of religious action which may have public manifestations; (3) the realm of action clearly public. It is usually agreed that the law cannot trifle with the first-no legislature may pass a law commanding people to believe in God. The issue is either to distinguish the latter two, or to provide principles to justify legal regulation of the second. We will do the former.

The distinction in tentative form is: religious action is action the function of which is only to establish and perpetuate a private meaning for individuals - a meaning given to it by a religion. Religious actions create results whose effects are private, felt only by those who believe or are concerned with belief. Some actions will occur which have real meaning or effect only in the world of ideas. Thus, purely symbolic actions may be distinguished from actions, such as polygamous cohabitation, which have tangible, worldly consequences. And among those actions which effect only the world of ideas are religious actions, defined as such by the religion which adopts them. That is, religious action takes place in but does not exhaust the realm where actions induce, signify, or reject beliefs. Public action, on the other hand, is that which affects others in ways not limited to their belief. Further, these effects, for the purpose of the law, must already have been described, prescribed, or proscribed by an authoritative decision of the governing political powers. This distinction should grow in meaning in the following discussion.

Religion serves as no defense to a law regulating what we have defined as public actions. Only if action can be seen to be exhausted in an individual's private affirmation, and relates to his assumption of a perspective, is it religious action and thereby sacrosanct. For example, buying a drug clearly warranted as "good" by religion and whose contents are not condemned by 
law concerns only the private individual in his belief. Erecting a building which does not meet public legal requirements is not defensible since that forbidden act affects people in a very tangible way if the building falls. In the first case, absent negative proscriptions, there is only an individual in the religious world. In the second case, by virtue of the existence of public demands regarding tangible conduct beyond the world of belief, we have activity in the public world.

West Virginia State Bd. of Ed. v. Barnette ${ }^{40}$ would seem to militate against this distinction. In that case, children of Jehovah's Witnesses had been dismissed from school for refusing to salute the American flag although an order had been passed defining this as a public duty. Some would say that in this case justice demands that religion not be allowed to function as a defense to a charge of not complying with a public standard. Mr. Justice Frankfurter's dissent put this point forcefully.

Much that is the concern of temporal authority affects the spiritual interest of men. But it is not enough to strike down a non-discriminatory law that it may hurt or offend some dissident view. It would be too easy to cite numerous prohibitions and injunctions to which laws run counter if the variant interpretations of the Bible were made the tests of obedience to law. The validity of secular laws cannot be measured by their conformity to religious doctrines. It is only in a theocratic state that ecclesiastical doctrines measure legal right or wrong. ${ }^{41}$

Mr. Justice Frankfurter distinguishes only between the realm of pure belief and the realm of action clearly public to use this distinction forcefully to reach his result. His opinion thus serves as a hard testing ground for the viability of the suggested third realm-that of religious action. The Jehovah's Witnesses are taught that saluting a flag is sacrilegious idolatry-the flag being a forbidden "image." The State Board of Education ordered the flag salute to be "a regular part of the program of activities in the public schools" with penalties attached for non-performance. Mr. Justice Jackson, for the majority, seemed to balance the public interest against private interests in the realm of belief, in the fashion of recent applications of a "balancing test" to free speech problems. ${ }^{42}$ His opinion can be read then, as teaching that the Frankfurter position might be right but that this regulation of opinions is unconstitutional because unjustified. Yet if this is the case, Mr. Justice Frankfurter's argument that religious rights are irrelevant once one is securely in the realm of public action is cogent. 43

One could, however, find a broader base for decision in this opinion-a base commensurate with our tripartite distinction. At one point Jackson discussed the fact that the involvement of creeds is an essential matter in the case. "If official power exists to coerce acceptance of any patriotic creed,

40. 319 U.S. 624 (1943).

41. Id. at 654 (emphasis supplied).

42. Id. at $638,640,641$.

43. This is particularly true for purposes of a "religious" objection to a regulation if we refuse to define religion. 
what it shall contain cannot be decided by courts, but must be largely discretionary with the ordaining authority, whose power to prescribe would no doubt include the power to amend." 44 He pointed out, at another place in the opinion, a focal fact of the case which would help to put the matter in the realm of privacy in accord with our distinction. "The freedom asserted by these appellees does not bring them into collision with rights asserted by any other individual. ... Nor is there any question in this case that their behavior is peaceable and orderly." ${ }^{.45}$ In terms of the suggested distinction, we might say that their action of refusal could affect only the beliefs of others. Given the absence of tangible negative effects upon others, Mr. Justice Jackson concluded in the now familiar words that

If there is any fixed star in our constitutional constellation, it is that no official, high or petty can prescribe what shall be orthodox in politics, nationalism, religion, or other matters of opinion or force citizens to confess by word or act their faith therein. If there are any circumstances which permit an exception they do not now occur to us. 46

The dispute in Barnette narrows sharply to one issue: in the realm of public life are there some regulations we will prohibit because of their effect on religious people? Mr. Justice Jackson found the answer in his opposition to belief coerced without justification. Mr. Justice Frankfurter found no exception on the grounds that such a determination interferes with the government's proper domain of regulation. Our tentative distinction provides an answer when we discriminate carefully among Mr. Justice Jackson's attacks on the regulation. We can agree with the Frankfurter position that religion should be no defense to a charge of disobeying public regulations. Yet when we examine the nature of the public demand in Barnette, we arrive at Mr. Justice Jackson's conclusions.

The argument is as follows: these people were neither doing something that is ordinarily regulated, nor doing something which detracts from the effectiveness of other regulations, nor avoiding doing something which is required as a duty to protect others. The first of these observations is reinforced by noting that the regulation is aimed at the realm of beliefs. The latter two are strengthened by recognizing Mr. Justice Jackson's point that a refusal to salute does not interfere with the rights of others. It therefore lacks the characteristics of public action in that it has no effect on people beyond the

44. 319 U.S. at 634.

45. Id. at 630 .

46. Id. at 642. To Mr. Justice Jackson's famous rhetoric Mr. Justice Frankfurter answered with his notion of religious freedom guaranteed by the Constitution. "[N]o religion shall either receive the state's support or incur its hostility. Religion is outside the sphere of political government. This does not mean that all matters on which religious organizations or beliefs may pronounce are outside the sphere of government." Id. at 654 . He further replies: "Of course patriotism cannot be enforced by the flag salute. But neither can the liberal spirit be enforced by judicial invalidation of illiberal legislation." $I d$. at 670. Mr. Justice Jackson was challenged to find something beyond notions of free expression on which to base invalidation of this regulation. It is, in part, this challenge that is answered by discrimination among beliefs for a religious defense. 
realm of their beliefs. Rather, the Board was calling on the Witnesses to affirm something against their will. They presented the children with a symbol and told them to act towards it in a certain way and invest it with a meaning of particular sort. A religion forbade such affirmations.

It is important to note exactly what type of action was called for. Its nature might have been more apparent if the required posture were more traditional. Suppose the regulation had required the children to kneel, fold their hands, close their eyes, and recite the pledge. A different position of hand than most people use to pray by does not make a ritual less a prayer. The action called for was one of private dedication rather than public participation. It defined a posture, a creed towards objects, symbols and beliefs. In short, this pledge had manifestations which are only cognizable by those who believe or those who are concerned with the beliefs of others. Such action was proscribed by the Jehovah's Witnesses.

Once it is granted that the Jehovah's Witnesses are a religion (since they both hold themselves out to be one and are easily recognizable as such) we can say that their refusal to salute is justifiable, not as a defense to a public demand on the ground of religion, but rather on the ground that the public standard invades that particular religion's particularly religious characteristics. Since the regulation achieves that impact with no justification other than encouraging the attitude of patriotism, it is invalid under the first amendment. We are not presented with a clash of perspective resulting from a legal definition of public results, but rather a clash which owes its origin to a regulation which defines actions designed to perpetuate a private meaning in conflict with a religion's private meaning.

This analysis does not use religion as a defense, but uses these religious objectors as an example to show that this regulation does invade the religious domain and involves no compensating public aspect. Law-makers may not themselves define what is a religion, nor can courts define what is an invasion of religious freedom in the abstract. But the religious objectors allow us to assess the public nature of this regulation. An affirmation is private, this regulation of affirmation is not a regulation of public action but an entrance into the religious sphere. Having no warrant in regard to public action the regulation must fall as prohibited once it can be shown that it invades a private realm, and seeks to order that realm in a manner contrary to an order imposed by a religion. In short, in the absence of a public justification, what condemns this regulation is its calling for affirmations. This the Justices condemn on free speech grounds. But we can go farther and suggest that it also may be condemnable under the "establishment" clause of the first amendment. The regulation's invasion of free speech suggests the establishing of a system of perspectives and affirmations. The Jehovah's Witnesses, by their objections, demonstrate that this system can have religious connotations and suggest an establishment question. ${ }^{47}$ Yet we need not go that far. What this

47. It is not clear whether the establishment question was at issue. An injunction was issued "restraining the State Board of Education from enforcing against them a 
case shows is that the first amendment's guarantee of religious freedom prevents the establishing of purely ritualistic actions or affirmations which can be shown to clash with a particular religion. In other words, religion can serve as a ground for attack or defense against public regulations when those regulations are formulated purely in the realm of affirmation and ritualistic posture. ${ }^{48}$

In defining the relation of religion and law under the aegis of the Constitution we have examined and defined what types of assaults religion is protected against, what comprises its defensible integrity and exemptions. To arrive at a fuller understanding of the functioning of religion in the context of legality it is necessary to explore the way in which religion may infect a legal situation, or a religious institution participate in a public process. We have focused on the individual's freedom to ask for any affirmation of belief commensurate with standards of public action. The question that arises naturally is the converse: What benefits may a religion claim, if it meets public standards for the granting of benefits? The famous "School Bus" case, Everson v. Board of Educ., ${ }^{49}$ offers an answer. Written by Justice Black, it is perhaps the most difficult decision in this area, and perhaps the most brilliant.

Before we approach that case, one preliminary case must be understood. Pierce v. Society of Sisters ${ }^{50}$ involved section 5259 of the Oregon statutes, regulation of the Board requiring children ... to salute the American flag." Barnette v. West Virginia State Bd. of Educ., 47 F. Supp. 251, 252 (1942). The judge's summary, however, reads without the phrase "against them" although he states the question of the case as whether or not the Jehovah's Witnesses can "lawfully be required to salute it." Ibid. The question is whether the ritual was attacked or the compulsion of the children to participate was held unconstitutional.

48. There is a sense in which any government establishment of ritual raises problems in the area of establishment of religion-although without a finding that religion is involved, the ritual is perhaps not assailable as such. Two separate concurrences suggest a concern with the meaning of establishing rituals relevant to belief. Mr. Justice Black, for himself and Mr. Justice Douglas, stated: "Religious faiths, honestly held, do not free individuals from responsibility to conduct themselves obediently to laws which are either imperatively necessary to protect society as a whole from grave and pressingly imminent dangers or which, without any general prohibition merely regulate time, place or manner of religious activity." 319 U.S. 624, 643 (1942). That pledge Mr. Justice Black regarded as a "test oath" and found "abhorrent," forbidden by the first amendment. His opinion notes that private rights underlie religious freedom. Mr. Justice Murphy puts the stress elsewhere. In a phrase suggesting Mr. Justice Black's general theory of amendments as commands he stated, "I have no loftier duty or responsibility than to uphold that spiritual freedom in its farthest reaches." Id. at 645 . To this end he suggested a test. "I am impelled to conclude that such a requirement is not essential to the maintenance of effective government and orderly society." Ibid. Mr. Justice Murphy also mentioned private rights. "To many it is deeply distasteful to join in a public chorus of affirmation of private belief. ... I am unable to agree that the benefits that may accrue to society from the compulsory flag salute are sufficiently definite and tangible to justify the invasion of freedom and privacy that is entailed." Id. at 645-46.

49. 330 U.S. 1 (1946).

50. 268 U.S. 510 (1925). 
which compelled all children between eight and sixteen to attend public schools. Two schools, one parochial, the other private, contested the constitutionality of this statute before the Supreme Court. Mr. Justice McReynolds, for a unanimous court, affirmed a decree which had declared the statute unconstitutional; to reach this result he used the first amendment, applying it to the state law through the due process clause of the fourteenth amendment.

No question is raised concerning the power of the State reasonably to regulate all schools, to inspect, supervise and examine them, their teachers and pupils; to require that all children of proper age attend some school ... and [to require] that nothing be taught which is manifestly inimical to the public welfare. ${ }^{51}$

Having thus defined the state's permissible sphere of supervision of education in abstract terms, Mr. Justice McReynolds went on to say "that the child is not merely a creature of the state. Those who rear him have the right and the duty to recognize and prepare him for additional obligations." 52 If a school fulfills certain public standards, the state has exhausted its legal interest in those who attend them. The state has a right to set educational standards, but not to dictate where they are to be fulfilled or what accompanying characteristics must be. More specifically, the case limited the state's power to control what a student learns.

Mr. Justice McReynolds seems to have justified this conclusion by reference to a conception of parental right to choose the school to which they send their children. Perhaps the rationale is that because the rights involved are inherent in individuals, state regulations impinging them must be limited to what is required by the public purpose. Some Catholics have offered the additional argument in support of the case that religious freedom compels its holding. ${ }^{53}$ To say that a school must have no religion, they argue, is to teach a theory of religion-that education and spiritual growth are separate. Such a theory runs counter to Catholic doctrine. It is thus a denial of Catholic religious freedom if parochial schools are outlawed. For then Catholics would be imprinted with a doctrine about religion which they do not accept. If, in fact, they fulfill the state's standards of education, shouldn't they be permitted to add on their own conditions? If everyone meets the state's standards and religious people meet them in their religious way, religion is served. If religious people are not so allowed, they are forced to practice what they preach against. Such an argument might call on our distinction of public actions from religious expression to say that to make Catholics go to a particular school only affects their beliefs. That conflict with an established religion's beliefs might be said to invade the domain of religious expression.

The difficulty with this argument is suggested by our earlier discussion of the conflict of perspectives. Religion is not always a clear or separable

51. Id. at 534 .

52. See id. at 535. Cf. Meyer v. Nebraska, 262 U.S. 390 (1923).

53. Murray, Laze or Prepossession, 14 Law \& Contexp. Prob. 23, 30-34, 36-37, 39 (1949). 
domain. Many a public pronouncement may imply a position that a religion may reject. If the law requires drivers to stay on the right, and a religion urges the left on grounds that God speaks only to people on the left, the law forces one to practice what one does not preach. Further, the fact that Catholics meet some public standards does not in itself justify a conclusion that they do not have to meet all such standards. In order to justify such a conclusion, one must show that the religion's demand is separable from the other public requirements and that the state's demand affecting that religious demand only affects beliefs. But non-ideological reasons for putting all pupils in public schools can be found. The state can say that such a requirement is the most reasonable way to perpetuate public regulation. A regulation compelling parents to send children to particular public standard schools is not clearly separable from the aim of maintaining those public standards, nor is it clearly in a realm only affecting belief.

It is perhaps safer to say that once religious beliefs are involved, we should look carefully, as in the Flag Sahute Case, to see that institutions of a religious nature are not established, and, that in general, we should try to permit maximum freedom for divergence. Under such a nebulous warrant, we find the Pierce case, as a matter of law, holding in favor of the freedom to educate up to standards in whatever place desired-a view bottomed on the parental right to freedom within the framework of public standards. Public standards dictate only certain educational requirements.

Given, then, that the state cannot dictate observance beyond its standards in education, the question arises as to what types of benefits the first amendment permits it to bestow on those agencies which both fulfill its standards and also partake of a religious nature. It is to this question that Black addressed himself in the "School Bus" case. ${ }^{54}$ At stake in Everson was the constitutionality of a New Jersey Board of Education's decision, made under statutory authority, to reimburse parents for "money expended by them for the bus transportation of their children on regular buslines operated by the public transportation system"55 to and from schools. The difficulty was that "part of this money was for the payment of transportation of some children in the community to Catholic parochial schools." ${ }^{6}$ Everson, "in his capacity as a district taxpayer, filed suit in a state court challenging the right of the Board to reimburse parents of parochial school students."

First, and most important, Mr. Justice Black established that he was examining the statute, not the particular practice in this town which happened to result in the giving of money only to Catholic school pupils. The Justice noted in a crucial footnote that the statute was not challenged under the equal protection clause for "excluding payment for the transportation of any
54. 330 U.S. 1 (1946).
55. Id. at 3.
56. Ibid.
57. Ibid. 
pupil who attends a 'private school run for profit.'"58 Given the limited nature of Mr. Justice Black's inquiry it is possible to reconstruct his argument from parts of the opinion.

The establishment of religion clause, he stated, means that

Neither a state nor the Federal Government can set up a church. Neither can pass laws which aid one religion, aid all religions, or prefer one religion over another. Neither can force nor influence a person to go to or to remain away from church against his will or force him to profess a belief or disbelief in any religion. ... No tax ... can be levied to support any religious activities or institutions, whatever they may be called, or whatever form they may adopt to teach or practice religion..$^{59}$

On the other hand, "That Amendment requires the state to be a neutral in its relations with groups of religious believers and non-believers; it does not require the state to be their adversary. State power is no more to be used so as to handicap religions than it is to favor them." state acts towards an organization, the question to ask is whether the state's action is in any sense determined by the religious characteristic of the organization. If it is, the action or the statute authorizing it is unconstitutional. On the other hand, if there are public standards, not a function of religion or belief, religion should furnish no excuse or reason for deviation. Black argued further that this reasoning applies to the allocation of benefits as well as to the promulgation of restraints.

Then, Mr. Justice Black asked, is there anything wrong with providing transportation to children attending schools? He saw no defect. Moreover, the statute certainly does not fall because of any religious characteristics, as there are none relevant to the standards in the statute. Since there is nothing constitutionally objectionable in the standards or statute, there is nothing wrong with applying the statute to schools which happen to be Catholic. Indeed, it would be unconstitutional to preclude the giving of aid to Catholic schools if others received aid. This is the nub of the case. Mr. Justice Black stated it with a type of reverse English.

While we do not mean to intimate that a state could not provide transportation only to children attending the public schools, we must be careful, in protecting the citizens of New Jersey against state-established churches, to be sure that we do not inadvertently prohibit New Jersey from extending its general state law benefits to all its citizens without regard to their religious belief. ${ }^{61}$

In effect, religion cannot be used to prevent extension of "general state law benefits." Once we find that a statute operates reasonably in dispensing benefits and is not defined by religion, freedom dictates that it be applied equally to those who mix religion in with the conditions of benefit. The constitutional mandate does not prevent all persons, religious and non-religious, from re-

58. Id. at n.2 (emphasis added). See also id. at 6 .

59. Id. at $15-16$.

60. Id. at 18 .

61. Id. at 16. 
ceiving those benefits. Indeed, since it is impossible to define a domain for religion, and since religions may introduce prescriptions into other domains, to decide the constitutionality of this kind of statute on the basis of "religion" is to decide on something which is not necessarily or directly at work in the secular choice itself.

Mr. Justice Black had yet another point to make.

State-paid policemen, detailed to protect children going to and from church schools from the very real hazards of traffic, would serve much the same purpose and accomplish much the same result as state provisions intended to guarantee free transportation of a kind which the state deems to be best for the school children's welfare. ${ }^{62}$

One could object that the policemen direct the traffic for the sake of order as well as for the sake of children, but this would not destroy the analogy between police protection and public transportation. Both function to facilitate choices of where to go, and both are justified if extended without predication on religious preference. It provides a public freedom to choose means, not an aid to the private practice of a state recognized religion.

Mr. Justice Black stated that there is a "difficulty in drawing the line between tax legislation which provides funds for the welfare of the general public and that which is designed to support institutions which teach religion." ${ }^{\prime \prime}$ In Everson, he had no difficulty.

It is much too late to argue that legislation intended to facilitate the opportunity of children to get a secular education serves no public purpose. ... Nor does it follow that a law has a private rather than a public purpose because it provides that tax raised funds will be paid to reimburse individuals on account of money spent by them in a way which furthers a public program. ... Subsidies and loans to individuals such as farmers and home owners, and to privately owned transportation systems, as well as many other kinds of businesses, have been commonplace practices in our state and national history. ${ }^{64}$

Where aid is given directly to institutions for apparently non-religious purposes, the difficulty in "drawing the line" might be heightened by the possibility that the guide for disbursement, which appears not to distinguish on a religious basis, cloaks a practical effect of so doing. But in Everson, the money was given to individuals, not to a church organization. The fact that it may be employed by individuals to help a church or to further a church program should be considered irrelevant and in the area of free choice. Admittedly this is a tenuous, easily blurred, sometimes quantitative distinction; it is true that aid to individuals could be in fact designed to be aid to a church. At a minimum, the distinction operates to indicate that the aid allows choice within a range not proscribed by public standards, rather than furnish aid to

62. Id. at 17 .

63. Id. at 14 .

64. Id. at 7. At this juncture Mr. Justice Black's citation of Cochran v. Louisiana State Bd. of Educ., 281 U.S. 370 (1930) is very important. See note 65 infra. 
religion. At a maximum, the distinction indicates that religion is not involved; the reimbursements are just aid to individuals. ${ }^{65}$

We can restate this part of the argument as follows: having justified the aid as allowing freedom of choice, there are two agencies of aiding to be examined. The agency of implementing the choice; the agency for distributing the benefit. The agency of implementing the choice is public transportation which is not defined by religion. It functions to serve all, in a way analogous to the way a policeman serves all. The agency for distributing benefits is the reimbursement of individuals. This is a traditional way of giving money for public programs, and as long as it is not predicated on religious discrimination it certainly does not fall afoul of the establishment clause. The statute is valid both in terms of the benefits distributed and the agencies chosen.

The soundness of Everson as a holding of law should be manifest, once the idea of parochial schools fulfilling public educational standards is accepted. If children can go to those schools they certainly can take buses there. Pierce suggested the focus on individuals that Black amplified into a distinction. Going to parochial schools is an acceptable way of fulfilling public standards. The conjunction of two propositions yields Everson's result: Law demands only that public standards be fulfilled, not that the perspectives of other domains be preempted. Public aid for private choice into which religion does not necessarily enter is acceptable.

We can reformulate the legal argument as follows: the Constitution prohibits aid to religion and support of any state religion. Everson presents a statute offering benefits to those who meet public standards and, only incidentally to statutory language or purpose, go to church schools. The statute does not breach the "wall of separation," since (a) the aid it authorized went to individuals as an expression of public policy towards private choice, (b) the statute was not defined in terms of religious goals, nor did it discriminate according to religious characteristics, (c) the benefactors fully met the requirements of the state in all relevant respects.

It is surprising that Mr. Justice Black's position found but a bare majority of the Court. Mr. Justice Jackson, whom one might have expected to follow, dissented. He saw the question as "Is it constitutional to tax this complainant to pay the cost of carrying pupils to Church schools of one specified denomination?"06 The majority opinion stated that the particular usage was not an issue in this case. ${ }^{67} \mathrm{Mr}$. Justice Rutledge was joined by Justices Frankfurter, Jackson and Burton in a thirty-six page dissent. ${ }^{68}$ His argument was based on the analogy of "An appropriation from the public treasury to pay the cost

65. Cochran v. Louisiana State Bd. of Educ., 281 U.S. 370 (1930) declaring constitutional the provision of free public school books to children at private and parochial schools, also supports the correctness of the Everson holding as a matter of law. In that case, it was said that "schools . . . are not the beneficiaries"-the children and the state are. $I d$. at 375 .

66. Everson v. Board of Educ., 330 U.S. 1, 21 (1947).

67. Id. at $4 \mathrm{n} .2$ and accompanying text.

68. Id, at 28 . 
of transportation to Sunday school . . . or to the meetings of various young people's religious societies ... [ [which] could not withstand the constitutional attack."69 But the analogy was false: this is not aid to exclusively religious facilities, but aid intended to facilitate the fulfillment of state standards in facilities recognized by the state as serving its public goals. That these facilities happen to offer an option as to the mixture of religion in education is irrelevant to the public purpose. ${ }^{70}$

In our framework, the sense of Mr. Justice Black's legal position emerges. To prevent aid when there is a possibility of encouraging religion would destroy our conceptual dichotomy of the domains and vitiate the idea that legal reasoning should proceed on the basis of their separateness even when both religion and other perspectives apply, in fact, to the same fact situation. Our position recognizes that, since the state and religions have different perspectives and different goals to be achieved by implementing certain regulations, to judge one by the other is to violate the mandate of the first amendment. If, after we have defined our public standards and our public aid exclusive of religious considerations, we then destroy them as a judicial matter because of some participant's religious characteristics, we once again enter into a judicial determination of a religious sphere. The fact that aid may foster the manifestations of belief does not make it aid to private religions expression. Such aid functions to affect people in a realm apart from belief. Easing the way to education makes it public action aid. The question is whether the public standards or public aid are dependent on an evaluation of private religious belief. ${ }^{71}$ If not, then to apply judicial reckoning is to enter the domain of religion forbidden under the first amendment.

The converse implications of this opinion can be suggested by a brief excursion into the Sunday Closing Law cases: McGowan v. Maryland, ${ }^{72}$ Two Guys from Harrison-Allentown $v$. McGinley, ${ }^{73}$ and Braunfield v. Brown. ${ }^{74}$ These cases involved the constitutionality of statutes which made it mandatory to close stores on Sunday. Since some Jews closed on Saturday in observance of their religion, it was argued that such a regulation was unconstitutional, because it penalized people for practicing their religion.

The Court did not find the laws unconstitutional-a result which may be justified as the converse of Everson. Just as we cannot invalidate aid because religious people may use it to benefit their religion, so we cannot invalidate regulations solely because people may be affected adversely in their religion. Since we cannot use the content of any particular religion to judge the

69. Id. at 47 .

70. The appositeness of the analogy might also be questioned in light of Zorach v. Clauson, 343 U.S. 306 (1952).

71. See text accompanying notes $86-93$ infra.

72. 366 U.S. 420 (1961).

73. 366 U.S. 582 (1961).

74. 366 U.S. 599 (1961). 
application of a public standard, we cannot strike down Sunday-closing legislation because it affects Jews. ${ }^{75}$

Two arguments can be made against this position. First, the statute is, in fact, designed to hurt Jews and as such infringes free religious practice; second, although the state has a right to declare that there should be a day of rest, it can show no non-religious reason to pick Sunday. This latter argument resembles those that Catholics have made about Pierce. A day of rest is justified, but not Sunday, if picking Sunday is but a manifestation of religious belief. The answer to the first argument is that malicious legislative intent has to be shown conclusively. If it is shown that the exclusive function and purpose of the law was to attack a particular religion then it is invalidbut such an allegation has no specific support, and secular reasons for having everybody closed the same day-for example, ease of enforcement-can be advanced to support choice of that day when most citizens will choose to rest. Again, it is impossible to separate this part of the regulation-the choice of day-from the whole public purpose, and the state has the right to define that one day which it thinks the stores should be closed. Many examples of difficulties in allowing religious criteria to affect closing regulations can be imagined. ${ }^{76}$ If one were to judge the choice of a day by its religious effects, this would be to do what the Ballard analysis showed to be a mistake-to entertain descriptions and accounts of religion. Rather, since the statute defines public action by regulating people in the operation of commerce, it does not enter into the range of private religious expression and cannot be judged by the fact that the goals of religion may coincide or clash with the actuality of the legal regulations unless an attempt to create such a clash can be clearly shown:

These principles of interpretation of the first amendment's commands, derived from Ballard, manifest in Everson and McGowan, and amplified by a distinction evidenced in Barnette, can be summarized as follows: (1) The function of the Constitution is to exclude calculation of religious values, be they motives for deceit, or aid, or violation of statutes. (2) The Constitution also prevents the formulating or examining of the possible private ways of acting on religious beliefs.

That these simple commands can be applied in other cases is demonstrated by an excursion into the recent and controversial school prayer case, Engel $v$. IVitale. ${ }^{77}$ Once again, Mr. Justice Black wrote the majority opinion. The prayer which the state prescribed for morning recitation was as follows: "Almighty God, we acknowledge our dependence upon Thee, and we beg Thy blessings upon us, our parents, our teachers, and our Country."78 The schools,

75. The strength of this statement has been considerably weakened as law by Sherbert v. Verner, 83 Sup. Ct. 1790 (1963). See text accompanying notes 86-93 infra.

76. Cf. Mr. Justice Black's opinion in Barnette, 319 U.S. 624, 643 (1943).

77. 370 U.S. 421 (1962).

78. Id. at 422 . 
unlike those in Barnette, did not compel any pupil to join in this affirmation over his or his parents' objections.

Mr. Justice Black based his argument on two points. "There can be no doubt that New York's state prayer program officially establishes the religious beliefs embodied in the Regents' prayer."79 The particular defect was that the state promulgated religious doctrines in the schools. Clearly that falls under the ban of state-established religions. Secondly; "When the power, prestige and financial support of government is placed behind a particular religious belief, the indirect coercive pressure upon religious minorities to conform to the prevailing officially approved religion is plain." 80 Given the existence of such compulsion towards belief, the case's similarity to Barnette becomes evident. The state uses its machinery to make people act in such a way as to affect their beliefs. To utilize schools for religious activities is to foster religion unconstitutionally. ${ }^{81}$

In short, the prayer is a religious formulation. Even to say that it is common to all religions is to prescribe for future religions. The prayer utilizes state machinery to foster a religion. Both are banned under the Constitution. The prayer functions to permit the state to define religious affirmations. That breaches the separation of the domains. ${ }^{82}$

Two recent Supreme Court actions, however, cannot be reconciled with the suggested approach to the problems of religion under the first amendment; they illustrate the confusion sometimes resulting from tenderness towards religious defenses. In Sherbert $v$. Verner, ${ }^{83} \mathrm{Mr}$. Justice Brennan,

79. Id. at 430 . See also $i d$. at 435 .

80. Id. at 431 .

81. Not only is the prayer religious, but it is clearly so. Imagine the furor if parochial schools were compelled to start with that prayer; or Jewish Orthodox Sabbath Schools, to use it before starting to teach Hebrew. The religious character of the ceremony was implicitly conceded by the state when it permitted religious objectors to abstain. In discussing other school prayers, Justice Goldberg, referring to this case, asked whether "the state cannot compose but can select?" 31 U.S.L. WeEK 3276 (March 5, 1963).

82. Mr. Justice Douglas, in concurring, took off from the constitutional financing of religious exercise to worry about all the uses of money involving state and religion. But the question is whether the money and the statute related to its expenditure function to give state aid to particular religious formulations of belief. Mr. Justice Stewart, on the other hand, noted that "God Save the United States and this Honorable Court" precedes the Court's session. If a similarity in nature of the ritual exists, we should strike down the Court's ritual. But that issue has not arisen, and may be distinguishable on grounds of vacuity. Mr. Justice Blacks footnote 21 is relevant here. Engel v. Vitale, 370 U.S. 421, 435 (1962). Mr. Justice Stewart also states that we, as a people, presuppose a Supreme Being though the Constitution does not say so. As legal argument such an invocation is very weak. It is a dictum from Zorach v. Clauson, supra note 70, which in allowing for released time from schools for religious services, affirmed as most important in McCollum v. Illinois, 333 U.S. 203 (1947), the fact that the classrooms were used for religious instruction and the force of the public school was used to promote that instruction. To use a dictum from a case which explicitly held that the use of classrooms for fostering religious exercises was a crucial constitutional defect to try to uphold the school prayer is almost weaker in law than constitutional analysis.

83. 374 U..S. 398 (1963). 
speaking for a majority which included Mr. Justice Black, concluded that the "benefits" of state unemployment compensation could not be kept from a Seventh Day Adventist, who could not get a job because she refused to work on Saturday. He reasoned that the opposite decision would condition the "availability of benefits upon . . . willingness to violate a cardinal principle of her religious faith." 84 In $R e$ Jennison, ${ }^{85}$ the Court hinted a willingness to extend this reasoning by remanding, for reconsideration in the light of Sherbert, the Minnesota Supreme Court's affirmance of a decision holding a woman in contempt of court for refusing jury duty on claimed religious grounds. ${ }^{86}$ The woman claimed the refuge of biblical command- "Judge not that ye shall not be judged"-in refusing her civic duty. ${ }^{87}$

To permit a religious defense in either of these cases is to adopt a view of the first amendment very different from that presented here. ${ }^{88}$ This different view finds in the Constitution and its amendments the suggestion of an ideal society, and supports that finding with a conception of constitutional interpretation designed to implement the discovered ideal in each fact situation. This view interprets the first amendment command of religious freedom as an instruction to decide each case so as to choose freedom for religious activities to the maximum degree consistent with social order. The establishment clause is interpreted as a complement to the command for freedom in that it prevents any one religion from gaining ascendance to the detriment of others. Religion is then an allowable defense to the operation of those rules which, although neutral in the abstract, in practice infringe particular religious practices-Sunday closing laws, laws outlawing polygamy, ${ }^{89}$ rules enforcing jury service, etc. And to foster the free exercise of religion, exemptions and benefits may be bestowed-tax exemptions for religions, draft exemptions for pious conscientious objectors, chaplains for the armed services. The role of the decision maker is the practical one of examining factual situations with the goal of structuring the legal order so as to reduce to the minimum its conflict with particular religions. ${ }^{90}$

84. Id. at 406 .

85. 84 Sup. Ct. 63 (1963).

86. - Minn, 一, 120 N.W.2d 515 (1963).

87. Id. at 516 .

88. This view was most ably suggested to me by Professor Alexander M. Bickel, whose friendly criticism has been an aid in many respects.

89. Cf. Davis v. Beason, 133 U.S. 333 (1890).

90. The scope of the balancing process involved, and the inherent slipperiness of the approach as a tool for sensitive inquiry, are suggested by Mr. Justice Frankfurter's dissent in West Virginia State Bd. of Educ. v. Barnette, 319 U.S. 624, 646 (1942). See also Prince v. Massachusetts, 321 U.S. 158 (1944) where a young Jehovah's Witness was held validly convicted for sale of magazines on Boston streets, in violation of a city ordinance. Rather than balancing religious interests with community interests, courts should treat all citizens before them equally, once it is shown that the community interests involved (here, protecting the health of minors) exist in the realm of public action. Of course, any argument that the statute was, in fact, directed at these particular religious distributions would also be treated independently of any considerations of balancing. 
As a principle of constitutional interpretation, this practical approach is neither exclusive nor-at least to the author ${ }^{21}$ - persuasive. In its particular application to the problem of religions operating in society, it presents many difficulties. Assessing or assisting particular religions-defining the concept "religion"- -not only tends to establish those religions but also seems to limit the domain of future religions by requiring them to be similar to present ones if they wish to claim similar defenses or benefits. The state should not define religion and, therefore, cannot pass laws or entertain defenses that are directed to the aid of particular religious establishments. The activities of religions have their meaning in their effects on religious peoples' assents-we do not want the state performing assessments in that domain. Further, the "practical results" of this alternative approach are not uniformly beneficial. How does the woman in Jennison differ from those pacifists who refuse to pay taxes to support war? Or Vivian Kellems, whose tax reprisals are based on anti-welfare sentiments? Are Jehovah's Witnesses or Catholics pleased that their religions are thought by Draft Boards not to justify pacifism or conscientious objection? In the implementation of standards of exemption designed to aid the practice of religions, many religious groups and many positions labeled as religious may be excluded, to the detriment of their freedom of religion.

I find no constitutional compulsion to give conscientious objectors exemptions, Mormons many wives, or churches freedom from taxes. More important, these goals can and must be achieved in a way that removes the state from the business of defining and enshrining religions. As the Second Circuit has very recently recognized, ${ }^{32}$ the exemption for conscientious objectors cannot be made dependent upon belief in a Supreme Being. Unfortunately, the Second Circuit failed to follow the logic of its position through, and implied that the state could establish a definition of religion-so long as it included non-deistic religions - and condition grant of the exemption upon belief in a "religion." The exemption should be made available on grounds of moral belief in the wrongness of war, because we tolerate dissent on a model of free society ; but we are not compelled to make the exemption available because that dissent is labeled "religious." Activities in a religious group might be one of the factors considered in granting such an exemption, but only in the process of determining sincerity. ${ }^{93}$ On similar grounds of tolerance,

91. Weiss, Book Review, 72 Y.ALE L.J. 1665 (1963).

92. United States v. Seeger, 326 F.2d 846 (2d Cir. 1964). See also United States v. Jakobson, 325 F.2d 409 (2d Cir. 1963), which found as religious a particular notion of "horizontal" relation to God. Seeger explicitly recognizes the conceptual difficulty of insisting upon a distinction between Jakobson's devotion to a mystical force of "Godness" and Daniel Seeger's compulsion to follow the paths of "goodness," suggesting further the efficacy of avoiding judicial analysis of religious content as a requirement for exemption.

93. A difficult problem for those who adopt the view that religious freedom just commands toleration of religious practices is found in H.R. REP. No. 7152, 88th Cong., 2d Sess., tit. 7, $\$ 704$ (b) (1964) (on unfair employment practices). It states: "It shall not be unlawful employment for an employer to refuse to hire . . . because of said person's atheistic practices and beliefs." The couching of a refusal in apparently non-religious terms might raise no difficulties for their views. I find five insurmountable constitutional objections. (1) In general, there is a violation of equal protection. (2) To define 
it would be advisable to permit polygamy for those who recognize its moral rectitude; yet there is no constitutional compulsion to do so. Persons who do not wish to judge on juries, for whatever moral grounds, are probably unfit for jury duty, and perhaps should be excused on that basis; but there is no constitutional compulsion to accept an excuse based on a personal reading of a religious document for failing to fulfill public duties in the realm of public action. Religions with charitable aspects might be granted tax exemptions as charities; but to discriminate between what is and is not "religious" as a basis for denial or grant of government benefits should be forbidden. In short, if it is true that freedom is benefited by giving exemptions to extreme groups when they do nothing of serious harm to the commonwealth, the religious nature of some of these groups should neither include or exclude them from the total class. When we run across results of apparent injustices, we can correct them, should we choose to, using notions of freedom for dissent, rather than definitions, confusions, and establishments of religions.

In sum, religion calls for affirmations and is expressed in actions manifesting those beliefs. It is protected by the first amendment when clearly represented as religious, but only in the realm of belief or pure manifestations affecting belief. The state operates in many perspectives and can regulate the public domain. Both the law's perspective and a particular religion's perspective may overlap in a particular fact situation. But the Constitution prevents law from entering the purely private domain of religious expression and belief. This implies that the state can neither tamper with nor examine religious affirmations nor prescribe religious perspectives. Moreover, the state cannot predicate its statutes or their application on the nature of an affirmation or its conjunction with a statute. Beyond the realm where the two are conjointly prescriptive, the lawyers' and judges' job is to apply the public standard and only that, once it is found that the statute's operation is not predicated upon a distinction in affirmation or belief. These categories allow us to develop a rationale for the most important of the Supreme Court's decisions involving religion, and to discriminate the range of permissible activities for purposes of future decisions. The task is to discern whether religion forms a variable in the statute's formulation or application by seeing whether an assumption or decision on a perspective of belief is called for. If so, then the statute is unconstitutional. If not, then religion can form neither a defense to its application nor a justification after application for calling the statute unconstitutional.

atheism as something special denies any atheist the status of a participant in religion. Confucianism causes trouble, as such a doctrine of interpretation would attempt a mistaken definition of religion. Cf. Seeger, supra note 92 . (3) To enact a statute about atheism on practice and belief and give it to someone to administer would lead to serious troubles. For one thing, it is probably unconstitutionally vague. For another, to allow government agents to decide about religion for qualification is to allow the state into religious decisions unconstitutionally. Torcaso v. Watkins, 367 U.S. 488 (1960). (4) There is an unconstitutional test oath implicit here. (5) To reject atheism as encouraging religion seems to be a law in its very terms "respecting the establishment of religion." 


\section{THE YALE LAW JOURNAL}

VOLUME 73


RoBERT A. BuRT
JoHN A. KosKxneN
ELLIOTT J. WEISS
WILLIAM C. WHITFORD
Note \& Comment
Editors

Jonathan A. Ater EDWARD L. Barlow RICHARD J. BRAEMER Michael, A. Brush Donald C. Christ JOSEPH D. ClaytoN EDWARD R. CoHEN Chardes J. Donahue, JR. Roger D. FELDMAN Stephen R. Field Thomas K. GiLHool Sherwin M. Goldoman James S. Gordon

Peter L. Strauss
Editor-in-Chief
Monroe E. Price
Executive Editor

John Griffiths

Paul Grossman Michael F. Halloran Charles R. Halpern JoHN D. Hoffrian MICHAEL J. Horowitz Alan D. Jacobson HowaRd J. KasLow RICHARD A. Katzive JoHN L. KRAFT Martin D. Krall Martin E. Lowy Rod MCMAHAN Joseph D. MANDEL

\author{
ROBERT E. COOPER \\ STEVEN M. UMIN \\ Article \& Book \\ Review Editors \\ ROGER W. TOMPKINS \\ Managing Editor
}

\author{
Daniel Marcus \\ LEONARD M. MARKS \\ Anita S. Martin \\ Charles M. Natean \\ Barbara H. Paul \\ Edward A. Perell \\ David A. RaHas \\ OWen J. Sloane \\ George P. Smith \\ Willard B. Taylor \\ Allan A. Tuttle \\ Michael A. VARET \\ JoHN A. YouNG
}

EARL W. SHAPIRo
Business Manager

\author{
ALICE C. TEARS \\ Business Secretary
}

\section{CONTRIBUTORS TO THIS ISSUE}

LAWRENCE M. FRIEDMAN. B.A. 1948; J.D. 1951; LL.M. 1953, University of Chicago.

Jonathan Werss. B.A. 1960; LL.B. 1963, Yale University.

GoRDon B. BALDwIN. B.A. 1950, Haverford College; LL.B. 1953, Cornell University.

NajeEB E. HaLABY. B.A. 1937, Stanford University; LL.B. 1940, Yale University. 